\title{
ALPK2 wt Allele
}

National Cancer Institute

\section{Source}

National Cancer Institute. ALPK2 wt Allele. NCI Thesaurus. Code C115983.

Human ALPK2 wild-type allele is located in the vicinity of $18 \mathrm{q} 21.31$ and is approximately $148 \mathrm{~kb}$ in length. This allele, which encodes alpha-protein kinase 2 protein, plays a role in the phosphorylation of serines and threonines in alpha-helical proteins. 